\title{
EFFECTS OF DEMOGRAPHIC INDICATORS ON PERCEPTIONS OF FOLLOWERS OF LEADERSHIP STYLES
}

\author{
Mayiana MITEVSKA-ENCHEVA
}

\begin{abstract}
The article presents results of a comparative analysis of leadership styles in the academic environment. Survey results display factors for the leadership styles in specific university circles. The survey was conducted in the period October $2015-$ March 2016 among 517 respondents in four Bulgarian universities. The assessment of leadership styles follows the methodology using the Multifactor Leadership Questionnaire. Conclusions have been drawn about the significant differences of the effects of demographic indicators. Data have been processed by means of the software SPSS-21. Results may be used in future analysis of the effects of leadership styles in the education and training for cybersecurity.
\end{abstract}

Keywords: leadership styles, Bulgarian universities.

The successful management of the organization on the whole and employees' behaviour in particular requires knowing the individual differences among people in the organization. This guarantees the understanding of specific reactions and behaviour of the subordinates. Being aware of the stable individual differences provides the opportunity for a better and more effective selection but also at a later stage for the optimum motivation, control, analysis, evaluation, predicting and directing of their behaviour.

Leadership styles represent the way to motivate people in achieving organizational goals as well as building behavioural models when working with people. ${ }^{1}$ The effective leadership style, according to the Situational Theory of Leadership, or the Theory of the Life Cycle, devised by Hersey and Blanchard ${ }^{2}$ also depends on the degree of maturity of the subordinates. The focus is on the concept of 'maturity,' the ability to take responsibility for a particular kind of behaviour. In order to implement an effective cycle, the leader should motivate his or her followers. Leadership is a process whereby one person influences a group of people in achieving a common goal and possesses certain personal qualities, which allows exerting influence on the group. ${ }^{3}$ 
The qualities could be a manifestation of curiosity; creative thinking; communication skills; a strong character; boldness; charisma; common sense. ${ }^{21}$ Within the organization, the leader is crowned with a high status, which also allows exerting influence on the members' behaviour. ${ }^{22}$

Of interest in this study is whether there are differences in the manifestations of styles of managers in surveyed universities dictated by various demographic factors. To detect differences, ANOVA was applied. Variables, a source of variation in the estimates, are the gender of the respondents, age, level of education, the total length of service and residence.

The main objective of the study is to trace the important role of various demographic variables on perceptions of followers about the styles of their leaders. It is assumed that leadership styles that are characterized by initiative and engage in activities in the organization would have a direct impact on people's behaviour in the organization. Moreover, it is natural to assume that any organization can register its own peculiar style imposed by the manager. This assumption includes the hypothesis of influence of demographic factors on the perceptions of subordinates about the styles of their leaders.

The study has drawn upon the Multifactor Leadership Questionnaire by Bass and Avolio. It has been adapted to suit the Bulgarian conditions by Karabeliova. ${ }^{10}$ The original structure of the factors in the questionnaire contains four dimensions that describe the transformational (charismatic) leadership style: 'Idealized influence (charisma), 'inspirational motivation,' the factor 'intellectual incentive,' and 'individualized attention.' Two dimensions that describe the Transactional leadership style'relative awards' and 'exceptions management' - and one dimension referring to the Avoidance (liberal) leadership style. The separate subscales demonstrate good consistency reliability. The results for the reliability of the various scales are similar to those of other researchers who have applied the method. This gives grounds to assert that the questionnaire can be used in Bulgarian conditions for registration of different leadership styles. This methodology can be used to study any change of leadership styles and to identify trends in their development related to dynamic changes in the external environment. It is assumed that personality, situational and positional factors will determine leadership styles. The aim is to detect trends in their development as a response to the future requirements of the external environment.

The sample includes 517 individuals surveyed in the period April 2014 - February 2015. The questionnaire has been attached to cover a particular group (see Table. 1). Several parameters have been set as a prior restraint in the choice of respondents. The study involved only people who have work experience of at least one calendar year. The condition to the respondents in executive positions was to be directly subordinate 
to their leaders at least one calendar year. The purpose of such a limitation is to provide the opportunity to explore a more objective assessment based on the specific impressions formed within the at least one year.

The analysis of the study results allows us to draw the necessary conclusions to reveal factors influencing the views of the staff about their leaders and to identify trends in the development and change of leadership styles. The answer to these questions is sought by means of variance analysis, the results of which are shown in the tables below.

Table 1: Distribution of respondents according to demographic criteria.

\begin{tabular}{|c|c|c|c|}
\hline & raphic variables & number & $\%$ \\
\hline \multirow{2}{*}{ Gender } & Males & 246 & 49 \\
\hline & Females & 256 & 51 \\
\hline \multirow{3}{*}{ Age } & Up to 21-year-olds & 109 & 21,7 \\
\hline & from 21 to 40 -year-olds & 377 & 75,1 \\
\hline & Over 40-year-olds & 16 & 3,2 \\
\hline \multirow{3}{*}{ Education } & Secondary & 170 & 33,9 \\
\hline & BAs & 300 & 59,8 \\
\hline & MAs & 32 & 6,4 \\
\hline \multirow{4}{*}{ Organizations } & Organization 1 & 297 & 59,2 \\
\hline & Organization 2 & 57 & 11,4 \\
\hline & Organization 3 & 54 & 10,8 \\
\hline & Organization 4 & 94 & 18,7 \\
\hline \multirow{2}{*}{ Workplace } & State & 164 & 32,7 \\
\hline & Private & 338 & 67,3 \\
\hline \multirow{4}{*}{ Residence } & Small residential settlement & 12 & 2,4 \\
\hline & Small town & 56 & 11,2 \\
\hline & Big city & 147 & 28,9 \\
\hline & Capital & 289 & 57,6 \\
\hline \multirow{2}{*}{ Position } & Managerial & 215 & 30 \\
\hline & Operational & 502 & 70 \\
\hline
\end{tabular}


Table 2: Differences in the opinions of employees on leadership styles of their managers by gender (males - 246; females - 256).

\begin{tabular}{|c|c|c|c|c|c|}
\hline Leadership styles & Gender & $\mathbf{x}$ & SD & $\mathbf{F}$ & $\mathbf{p}$ \\
\hline \multirow{2}{*}{ Idealized influence, charisma } & Male & 9,32 & 3,43 & \multirow{2}{*}{15,09} & \multirow{2}{*}{0,000} \\
\hline & Female & 10,49 & 3,35 & & \\
\hline \multirow{2}{*}{ Inspirational motivation } & Male & 9,63 & 3,17 & \multirow{2}{*}{5,91} & \multirow{2}{*}{0,015} \\
\hline & Female & 10,3 & 3,01 & & \\
\hline \multirow{2}{*}{ Intellectual incentive } & Male & 8,64 & 3,72 & \multirow{2}{*}{11,46} & \multirow{2}{*}{0,001} \\
\hline & Female & 9,68 & 3,18 & & \\
\hline \multirow{2}{*}{ Individualized attention } & Male & 8,74 & 3,45 & \multirow{2}{*}{13,13} & \multirow{2}{*}{0,000} \\
\hline & Female & 9,82 & 3,22 & & \\
\hline \multirow{2}{*}{ Relative awards } & Male & 8,92 & 3,63 & \multirow{2}{*}{2,29} & \multirow{2}{*}{0,131} \\
\hline & Female & 9,38 & 3,12 & & \\
\hline \multirow{2}{*}{ Exceptions management } & Male & 10,4 & 2,70 & \multirow{2}{*}{19,46} & \multirow{2}{*}{0,000} \\
\hline & Female & 11,4 & 2,34 & & \\
\hline \multirow{2}{*}{ Liberal leadership } & Male & 9,19 & 3,34 & \multirow{2}{*}{16,76} & \multirow{2}{*}{0,000} \\
\hline & Female & 10,5 & 2,81 & & \\
\hline
\end{tabular}

Based on the results of ANOVA it may be noted that no significant gender differences in the perceptions of charismatic leadership are seen $(F=15.09 ; \mathrm{p}=0.000)$, intellectual incentive $(\mathrm{F}=11.46 ; \mathrm{p}=0.001)$, exceptions management $(\mathrm{F}=19.46 ; \mathrm{p}=0.000)$ and liberal leadership $(\mathrm{F}=16.76 ; \mathrm{p}=0.000)$. Female managers in the sample were rated as more liberal in management, considering the greater differences in opinions and acts of employees in the organization. In addition, women more than men managers, according to the opinion of subordinates, look into their individual differences and take them into account when assigning tasks and evaluating the performance. In other words, women in higher levels tend to pay attention to the individual approach when managing the organization. This result shows that there are some differences in leadership effectiveness between men and women leaders. However, it should be considered that men are perceived as exhibiting more leadership which is oriented to the whole. They often engage a more autocratic managerial style than women. In contrast, women are perceived as exhibiting more socially oriented leadership, increasingly using democratic or participatory style than men, which is confirmed by the results of this study. ${ }^{9}$ 
The rationale of the results can be sought in the direction of gender roles. Although gender-role stereotypes construct images of man and woman as a requirement for entry into different roles and implementation of various functions in modern society the trend has been towards unification of both sexes. Much of the functions and tasks considered a priority to men have already been recognized by female ones - building a career, occupying leadership positions. Leadership of women is established as a leading trend and is seen as the new competitive advantage of organizations. When in managing we involve both female and male skills and abilities, when conditions are provided for developing different creativity of both sexes new value is added to organizational effectiveness. ${ }^{10}$

Table 3: Differences in employees' on leadership styles according to age (up to 21-year-olds. - 109; from 21 to 40-year-olds. -377; over 40-year-olds-16)

\begin{tabular}{|c|c|c|c|c|c|}
\hline Leadership styles & Age & $\mathbf{x}$ & SD & $\mathbf{F}$ & $\mathbf{p}$ \\
\hline \multirow{3}{*}{$\begin{array}{l}\text { Idealized influence, } \\
\text { charisma }\end{array}$} & Up to 21-year-olds & 8,74 & 3,00 & \multirow{3}{*}{13,17} & \multirow{3}{*}{,000 } \\
\hline & from 21 to 40 -year-olds & 10,14 & 3,50 & & \\
\hline & Over 40-year-olds & 12,75 & 1,57 & & \\
\hline \multirow{3}{*}{$\begin{array}{l}\text { Inspirational } \\
\text { motivation }\end{array}$} & Up to 21-year-olds & 8,79 & 1,95 & \multirow{3}{*}{15,92} & \multirow{3}{*}{, 000} \\
\hline & from 21 to 40 -year-olds & 10,20 & 3,30 & & \\
\hline & Over 40-year-olds & 12,69 & 1,96 & & \\
\hline \multirow{3}{*}{$\begin{array}{l}\text { Intellectual } \\
\text { incentive }\end{array}$} & Up to 21-year-olds & 7,82 & 2,90 & \multirow{3}{*}{16,14} & \multirow{3}{*}{, 000} \\
\hline & from 21 to 40 -year-olds & 9,44 & 3,52 & & \\
\hline & Over 40-year-olds & 12,19 & 3,39 & & \\
\hline \multirow{3}{*}{$\begin{array}{l}\text { Individualized } \\
\text { attention }\end{array}$} & Up to 21-year-olds & 8,10 & 2,64 & \multirow{3}{*}{36,12} & \multirow{3}{*}{, 000} \\
\hline & from 21 to 40 -year-olds & 9,52 & 3,48 & & \\
\hline & Over 40-year-olds & 12,31 & 2,36 & & \\
\hline
\end{tabular}




\begin{tabular}{|c|c|c|c|c|c|}
\hline \multirow{3}{*}{ Relative awards } & Up to 21-year-olds & 8,17 & 2,38 & \multirow{3}{*}{14,97} & \multirow{3}{*}{,000 } \\
\hline & from 21 to 40 -year-olds & 9,36 & 3,60 & & \\
\hline & Over 40-year-olds & 11,00 & 2,10 & & \\
\hline \multirow{3}{*}{$\begin{array}{l}\text { Exceptions } \\
\text { management }\end{array}$} & Up to 21-year-olds & 10,34 & 2,06 & \multirow{3}{*}{5,10} & \multirow{3}{*}{, 006} \\
\hline & from 21 to 40 -year-olds & 11,02 & 2,67 & & \\
\hline & Over 40-year-olds & 12,19 & 2,14 & & \\
\hline \multirow{3}{*}{ Liberal leadership } & Up to 21 -year-olds & 8,47 & 2,56 & \multirow{3}{*}{19,93} & \multirow{3}{*}{,000 } \\
\hline & from 21 to 40 -year-olds & 10,18 & 3,22 & & \\
\hline & Over 40-year-olds & 11,81 & 1,60 & & \\
\hline
\end{tabular}

The results of the statistical procedures show that age differentiates seven meaningful leadership styles: idealized influence $(\mathrm{F}=13.17 ; \mathrm{p}=0.000)$, inspirational motivation $(\mathrm{F}=15.92 ; \mathrm{p}=0.000)$, intellectual incentive $(\mathrm{F}=16.14 ; \mathrm{p}=0.000)$, individualized attention $(\mathrm{F}=36.12 ; \mathrm{p}=0.000)$, relative awards $(\mathrm{F}=14.97 ; \mathrm{p}=0.000)$, exceptions management $(\mathrm{F}=5.10 ; \mathrm{p}=0.006)$ and liberal leadership $(\mathrm{F}=19.93 ; \mathrm{p}=0.000)$. There is a tendency with increasing age of employees to raise assessments on the applied leadership styles (see table 3). Logical explanation of the results could be found in the assumption that with the increasing of age more expectations are brought in terms of its contribution to the organization and its development. If in the earlier stages of life a person is focused around his or her own existence, with engaging in work it is changing.

According to the study residence is a source of variation for each of the leadership styles. The higher are the average results of respondents in big cities.

The participation of individuals in an organization can be described as motivated; employees expect a leader to fulfil his or her role as competent and concerned about their development. The leaders, according to respondents, maintain big emotional distance in hierarchical relations and give the social interaction intellectual incentive and mentoring. It is reasonable to believe that it is the respondents from smaller settle- 
Table 4: Differences in employees' opinions on leadership styles of managers depending on residence

\begin{tabular}{|c|c|c|c|c|c|}
\hline Leadership styles & Residence & $\mathbf{x}$ & SD & $\mathbf{F}$ & $\mathbf{p}$ \\
\hline \multirow{4}{*}{$\begin{array}{l}\text { Idealized influence, } \\
\text { charisma }\end{array}$} & Small residential settlement & 7,67 & 2,50 & \multirow{4}{*}{11,42} & \multirow{4}{*}{0,000} \\
\hline & Small town & 10,34 & 3,00 & & \\
\hline & Big city & 11,12 & 2,70 & & \\
\hline & Capital & 9,33 & 3,70 & & \\
\hline \multirow{4}{*}{$\begin{array}{l}\text { Inspirational } \\
\text { motivation }\end{array}$} & Small residential settlement & 8,67 & 2,00 & \multirow{4}{*}{10,27} & \multirow{4}{*}{0,000} \\
\hline & Small town & 10,55 & 2,71 & & \\
\hline & Big city & 11,00 & 3,00 & & \\
\hline & Capital & 9,40 & 3,13 & & \\
\hline \multirow{4}{*}{$\begin{array}{l}\text { Intellectual } \\
\text { incentive }\end{array}$} & Small residential settlement & 7,58 & 2,57 & \multirow{4}{*}{17,29} & \multirow{4}{*}{0,000} \\
\hline & Small town & 9,27 & 3,68 & & \\
\hline & Big city & 10,79 & 3,10 & & \\
\hline & Capital & 8,41 & 3,41 & & \\
\hline \multirow{4}{*}{$\begin{array}{l}\text { Individualized } \\
\text { attention }\end{array}$} & Small residential settlement & 7,58 & 3,48 & \multirow{4}{*}{19,48} & \multirow{4}{*}{0,000} \\
\hline & Small town & 9,95 & 3,52 & & \\
\hline & Big city & 10,83 & 3,03 & & \\
\hline & Capital & 8,47 & 3,22 & & \\
\hline \multirow{4}{*}{ Relative awards } & Small residential settlement & 9,25 & 3,09 & \multirow{4}{*}{18,74} & \multirow{4}{*}{0,000} \\
\hline & Small town & 9,68 & 3,52 & & \\
\hline & Big city & 10,69 & 3,12 & & \\
\hline & Capital & 8,27 & 3,21 & & \\
\hline $\begin{array}{l}\text { Exceptions } \\
\text { management }\end{array}$ & Small residential settlement & 9,75 & 3,00 & 8,78 & 0,006 \\
\hline
\end{tabular}




\begin{tabular}{|c|c|c|c|c|c|}
\hline & Small town & 10,86 & 2,77 & & \\
\hline & Big city & 11,77 & 2,42 & & \\
\hline & Capital & 10,53 & 2,48 & & \\
\hline \multirow{4}{*}{ Liberal leadership } & Small residential settlement & 9,33 & 2,37 & \multirow{4}{*}{11,80} & \multirow{4}{*}{0,000} \\
\hline & Small town & 10,15 & 3,10 & & \\
\hline & Big city & 11,06 & 2,64 & & \\
\hline & Capital & 9,22 & 3,25 & & \\
\hline
\end{tabular}

ments who emphasize the coordination within the organization and proactive behaviour aiming at stability in search of a place for their 'products' in an innovative way.

On the other hand, employees are expected to pursue new horizons of personal growth and career advancement. It has also been concluded that to meet the objectives in the workplace, team members strive to comply with rules, instructions and procedures for carrying out tasks.

Statistically significant differences have been observed in the assessments depending on the level of education (see table 5).

Table 5: Differences in assessments of leadership styles according to education (secondary - 170; BAs - 300; MAs - 32)

\begin{tabular}{|c|c|c|c|c|c|}
\hline Leadership styles & Education & $\mathbf{X}$ & SD & $\mathbf{F}$ & $\mathbf{p}$ \\
\hline \multirow{3}{*}{$\begin{array}{l}\text { Idealized influence, } \\
\text { charisma }\end{array}$} & Secondary & 9,43 & 3,36 & \multirow{3}{*}{3,7} & \multirow{3}{*}{0,012} \\
\hline & BAs & 10,46 & 3,48 & & \\
\hline & MAs & 10,66 & 3,28 & & \\
\hline \multirow{3}{*}{$\begin{array}{l}\text { Inspirational } \\
\text { motivation }\end{array}$} & Secondary & 9,92 & 2,99 & \multirow{3}{*}{1,39} & \multirow{3}{*}{0,246} \\
\hline & BAs & 10,19 & 2,77 & & \\
\hline & MAs & 10,5 & 3,00 & & \\
\hline \multirow{3}{*}{ Intellectual incentive } & Secondary & 9,13 & 3,42 & \multirow{3}{*}{1,46} & \multirow{3}{*}{0,225} \\
\hline & BAs & 9,23 & 3,61 & & \\
\hline & MAs & 10,28 & 3,30 & & \\
\hline
\end{tabular}




\begin{tabular}{|c|c|c|c|c|c|}
\hline \multirow{3}{*}{$\begin{array}{l}\text { Individualized } \\
\text { attention }\end{array}$} & Secondary & 9,45 & 3,57 & \multirow{3}{*}{2,15} & \multirow{3}{*}{0,094} \\
\hline & BAs & 9,24 & 3,36 & & \\
\hline & MAs & 10,47 & 2,86 & & \\
\hline \multirow{3}{*}{ Relative awards } & Secondary & 8,49 & 3,82 & \multirow{3}{*}{4,31} & \multirow{3}{*}{0,005} \\
\hline & BAs & 9,65 & 3,41 & & \\
\hline & MAs & 10 & 2,82 & & \\
\hline \multirow{3}{*}{$\begin{array}{l}\text { Exceptions } \\
\text { management }\end{array}$} & Secondary & 11,06 & 2,56 & \multirow{3}{*}{0,79} & \multirow{3}{*}{0,502} \\
\hline & BAs & 10,75 & 2,76 & & \\
\hline & MAs & 11,34 & 2,56 & & \\
\hline \multirow{3}{*}{ Liberal leadership } & Secondary & 9,88 & 3,58 & \multirow{3}{*}{4,63} & \multirow{3}{*}{0,003} \\
\hline & BAs & 9,92 & 2,78 & & \\
\hline & MAs & 11,56 & 2,76 & & \\
\hline
\end{tabular}

Charismatic leadership styles and liberal leadership are preferred by people with higher education. This does not apply to the management style of exceptions, styles of inspirational motivation and intellectual incentives, as well as the style labelled as 'individualized consideration.' It turns out that leadership style is dependent on the educational background of the respondents.

Work experience in the organization distinguishes statistically and significantly staff regarding their perception of applied leadership styles.

Respondents with up to 1 year of work experience, as well as those with over 10 years of experience assess highly the leadership styles in the organization, unlike those with work experience of between 1 to 10 years, who are more sceptical of the managerial impact of their managers. Originally, probably high estimates are given due to the desire of employees to convince themselves of the correctness of their choice of organization. The appreciation of the various manifestations of leadership styles is the result of more trust in the leader and the lack of information about his or her capabilities and relationships with the subordinates.

Subsequently, the group with experience from 1 to 10 years have accumulated some experience and knowledge of the strengths and weaknesses of the leader, becoming more critical and reducing its positive assessment. 
Table 6: Differences in assessments of leadership styles according to working experience in the organization

(up to 1 year-248; from 1 to 10 years - 238; over 10 years - 16)

\begin{tabular}{|c|c|c|c|c|c|}
\hline Leadership styles & Work experience & $\mathbf{M}$ & SD & $\mathbf{F}$ & Sig. \\
\hline \multirow{3}{*}{ Idealized influence, charisma } & Up to 1 year & 10,33 & 3,49 & \multirow{3}{*}{6,03} & \multirow{3}{*}{,003 } \\
\hline & From 1 to 10 years & 9,39 & 3,38 & & \\
\hline & Over 10 years & 11,31 & 1,85 & & \\
\hline \multirow{3}{*}{ Inspirational motivation } & Up to 1 year & 10,08 & 3,01 & \multirow{3}{*}{, 30} & \multirow{3}{*}{,742 } \\
\hline & From 1 to 10 years & 9,87 & 3,27 & & \\
\hline & Over 10 years & 9,88 & 1,75 & & \\
\hline \multirow{3}{*}{ Intellectual incentive } & Up to 1 year & 9,46 & 3,56 & \multirow{3}{*}{2,20} & \multirow{3}{*}{, 112} \\
\hline & From 1 to 10 years & 8,83 & 3,47 & & \\
\hline & Over 10 years & 9,75 & 2,44 & & \\
\hline \multirow{3}{*}{ Individualized attention } & Up to 1 year & 9,50 & 3,44 & \multirow{3}{*}{1,07} & \multirow{3}{*}{,345 } \\
\hline & From 1 to 10 years & 9,06 & 3,36 & & \\
\hline & Over 10 years & 9,50 & 2,56 & & \\
\hline \multirow{3}{*}{ Relative awards } & Up to 1 year & 9,72 & 3,35 & \multirow{3}{*}{7,55} & \multirow{3}{*}{, 001} \\
\hline & From 1 to 10 years & 8,55 & 3,39 & & \\
\hline & Over 10 years & 9,31 & 2,18 & & \\
\hline \multirow{3}{*}{ Exceptions management } & Up to 1 year & 11,18 & 2,48 & \multirow{3}{*}{4,72} & \multirow{3}{*}{,009 } \\
\hline & From 1 to 10 years & 10,56 & 2,63 & & \\
\hline & Over 10 years & 11,88 & 2,39 & & \\
\hline \multirow{3}{*}{ Liberal leadership } & Up to 1 year & 10,23 & 3,23 & \multirow{3}{*}{3,41} & \multirow{3}{*}{,034 } \\
\hline & From 1 to 10 years & 9,50 & 3,11 & & \\
\hline & Over 10 years & 9,56 & 1,71 & & \\
\hline
\end{tabular}

After a long stay in the organization under the influence of the leader (the group with over 10 years of experience) an increase is observed again in the positive assessment of the manifestations of different leadership styles.

It is very likely that part of people disagree with leadership impacts; they have attempted to leave this working environment, and some even have succeeded. Others who in the current survey are respondents from the third group with work experience of over 10 years, continue to work in the environment. They have expressed a posi- 
tive assessment of leadership styles to make their stay in the organization more bearable and suffer no significant mental consequences of their adherence to the environment.

The studied Organizations significantly differentiate the leadership styles (Table 7).

Table 7: Differences in the assessments of leadership styles according to the studied Organizations

\begin{tabular}{|c|c|c|c|c|c|}
\hline Leadership styles & Place & $\mathbf{x}$ & SD & $\mathbf{F}$ & $\mathbf{p}$ \\
\hline \multirow{4}{*}{$\begin{array}{l}\text { Idealized influence, } \\
\text { charisma }\end{array}$} & Organization 1 & 9,45 & 3,67 & \multirow{4}{*}{12,19} & \multirow{4}{*}{0,000} \\
\hline & Organization 2 & 9,84 & 3,53 & & \\
\hline & Organization 3 & 9,33 & 2,43 & & \\
\hline & Organization 4 & 11,77 & 3,02 & & \\
\hline \multirow{4}{*}{$\begin{array}{l}\text { Inspirational } \\
\text { motivation }\end{array}$} & Organization 1 & 9,6 & 3,15 & \multirow{4}{*}{16,17} & \multirow{4}{*}{0,000} \\
\hline & Organization 2 & 9,86 & 2,47 & & \\
\hline & Organization 3 & 8,89 & 2,35 & & \\
\hline & Organization 4 & 11,83 & 3,00 & & \\
\hline \multirow{4}{*}{ Intellectual incentive } & Organization 1 & 8,59 & 3,51 & \multirow{4}{*}{19,98} & \multirow{4}{*}{0,000} \\
\hline & Organization 2 & 8,93 & 2,64 & & \\
\hline & Organization 3 & 8,48 & 3,14 & & \\
\hline & Organization 4 & 11,54 & 3,13 & & \\
\hline \multirow{4}{*}{$\begin{array}{l}\text { Individualized } \\
\text { attention }\end{array}$} & Organization 1 & 8,55 & 3,21 & \multirow{4}{*}{26,79} & \multirow{4}{*}{0,000} \\
\hline & Organization 2 & 9,53 & 3,00 & & \\
\hline & Organization 3 & 8,7 & 3,10 & & \\
\hline & Organization 4 & 11,84 & 3,04 & & \\
\hline \multirow{4}{*}{ Relative awards } & Organization 1 & 8,67 & 3,41 & \multirow{4}{*}{17,7} & \multirow{4}{*}{0,000} \\
\hline & Organization 2 & 9,7 & 2,64 & & \\
\hline & Organization 3 & 7,76 & 2,95 & & \\
\hline & Organization 4 & 11,13 & 3,09 & & \\
\hline \multirow{3}{*}{$\begin{array}{l}\text { Exceptions } \\
\text { management }\end{array}$} & Organization 1 & 10,59 & 2,49 & \multirow{3}{*}{16,09} & \multirow{3}{*}{0,000} \\
\hline & Organization 2 & 10,51 & 2,59 & & \\
\hline & Organization 3 & 10,35 & 2,15 & & \\
\hline
\end{tabular}




\begin{tabular}{|c|c|c|c|c|c|}
\hline & Organization 4 & 12,49 & 2,45 & & \\
\hline \multirow{4}{*}{ Liberal leadership } & Organization 1 & 9,23 & 3,25 & \multirow{4}{*}{25,9} & \multirow{4}{*}{0,000} \\
\hline & Organization 2 & 9,49 & 2,16 & & \\
\hline & Organization 3 & 9,56 & 2,10 & & \\
\hline & Organization 4 & 12,26 & 2,71 & & \\
\hline
\end{tabular}

As can be seen from the data in one of the Organizations higher values of the assessments of leadership styles were observed, in comparison with the other Organizations. It can be assumed that managers there demonstrate specific and optimal style for a given situation which is perceived well by the followers. And since this approach in evaluations has been applied to each of the leadership styles, it is obvious that the leadership of this organization has managed to balance his or her influence on subordinates.

In conclusion it can be said that some of the indicators specific to the environment or respondents are able to actively influence staff's assessment and ultimately the formation of attitude towards leaders. This inevitably affects both the willingness to perform the tasks and the loyalty of employees, as well as the desire to follow their leaders.

\section{Acknowledgement}

The paper has been written under the Scientific Research Project, financed under Decree number 3 by contract \# NIP-2016 State University of Library Studies and Information Technologies.

\section{References}

1. Nwachukwu Prince Ololube, Handbook of Research on Organizational Justice and Culture in Higher Education Institutions ((Ignatius Ajuru University of Education, Nigeria, 20 April 2016), 571.

2. Paul Hersey and Kenneth H. Blanchard, Management of Organizational Behavior - Utilizing Human Resources, 6th edition (Englewood Cliffs, NJ: Prentice Hall, 1969).

3. Peter G. Northouse, Leadership: Theory and Practice (Thousand Oaks, CA: Sage, 2007), 365.

4. "Biznes-zhurnal, 2007/08: Nizhegorodskaya oblast," Biznes-zhurnal. Obiedinennaya mezhregionalnaya redaktsiya 08 (2007): 84. 
5. Robert Alpern, Michael Caplan, and Orson Moe, Seldin and Giebisch's The Kidney: Physiology and Pathophysiology, 5th Edition (London: Academic Press, 2012), 3290.

6. Stephen J. Zaccaro, Cary Kemp, and Paige Bader, "Leader traits and attributes," in The Nature of Leadership, ed. J. Antonakis, A. T. Cianciolo, and R. J. Sternberg (Thousand Oaks, CA: Sage, 2004), 101-124.

7. Milen Milanov and Sonya Karabeliova, "Negative Attitudes to the Roma Minority and Their Connection to Patriotism and Self-Assessment in Bulgarian Context [Negativni naglasi kum romskoto maltsinstvo i vzaimovruzkata im s patriotizma i samootsenkata v bulgarski kontekst]," Bulgarian Journal of Psychology [Bulgarsko spisanie po psihologiya] 3, no. 4 (2011): 387-392.

8. Zhivko Tiutiunkov, "The Individual and His Self-Assessment [Chovekut i negovata samootsenka]," Psychology journal 30 (December 2006).

9. Alice H. Eagty, Bruce G. Klonsky, and Mona G. Makhijani, "Gender and Effectiveness of Leaders: A Meta-Analysis," Psychological Bulletin 117, no 1 (January 1995): 125-145.

10. Sonya Karabeliova, "Dynamics of Value Organizations and Cultural Practices in the Bulgarian Socio-Cultural Context [Dinamika na tsennostnite organizatsii i kulturnite praktiki v bulgarskiya sotsiokulturen kontekst]," Resume of dissertation (Sofia: "Sv. Kliment Okhridski” University, 2012).

11. Bernard M. Bass, and Bruce J. Avolio, Improving Organizational Effectiveness through Transformational Leadership (Thousand Oaks, CA: Sage, 1994).

12. Bernard M. Bass, Transformational Leadership: Industrial, Military, and Educational Impact (Mahwah, NJ: Erlbaum, 1998), 35.

13. Bernard M. Bass, "Does the Transactional-Transformational Leadership Paradigm Transcend Organizational and National Boundaries?" American Psychologist 52, no. 2 (February, 1997): 130-139.

14. Bernard M. Bass, Bass \& Stogdill's Handbook of Leadership: Theory, Research, and Managerial Applications, 3rd ed. (New York: Free Press, 1990).

15. Bernard M. Bass and Bruce J. Avolio, "Transformational Leadership: A Response to critiques," in Psychology at Work, ed. Peter Warr (London: Penguin Books, 1993), 300-326.

16. Morris Rosenberg, Society and the Adolescent Self-Image, Revised edition (Middletown, CT: Wesleyan University Press, 1989).

17. Simon L. Dolan, Stress, Self-Esteem, Health and Work (Springer, 2006), 263

18. Bernard M. Bass and Ruth Bass, The Bass Handbook of Leadership: Theory, Research, and Managerial Applications, 4th edition (New York: Simon and Schuster, 2009), 1296.

19. Bernard M. Bass, Leadership and performance beyond expectations (New York: Free Press, 1985), 191. 
20. Bruce J. Avolio and Bernard M. Bass, "Individual Consideration Viewed at Multiple Levels of Analysis: A Multi-level Framework for Examining the Diffusion of Transformational Leadership," The Leadership Quarterly 6, no. 2 (Summer 1995): 199-218, https://doi.org/10.1016/1048-9843(95)90035-7; Jay A. Conger and Rabindra N. Kanungo, Charismatic Leadership in Organizations (Thousand Oaks, CA: Sage, 1998), 296.

21. Robert House and Denise Rousseau, On the Bifurcation of OB or It Ain't MESO It Ain't $O B$ (Philadelphia, PA: The Wharton School of Management, University of Pennsylvania, 1993).

22. Mariya Neikova, "Decentralization of Municipalities to Municipalities - Shortening the Distance Between Citizens and the Government," Legal collection 20 (2013).

\section{About the author}

Mayiana MITEVSKA-ENCHEVA is Doctor of Science in Psychology and Professor in the National Security Department at the University of Library Science and Information Technologies, Sofia. She is also Deputy Director of the Institute for Research and Development of Leadership in the Information Environment. Author of eight books in the field of psychology of security and organizational behaviour.

E-mail: majana@abv.bg. 